\title{
ВИКОРИСТАННЯ “РІВНІВ НАВЧАННЯ” ДЛЯ ОЦІНКИ ЗНАНЬ СТУДЕНТІВ НА ЦИКЛІ “ПСИХІАТРІЯ. НАРКОЛОГІЯ”
}

\author{
І. Д. Спіріна, С. В. Рокутов, Р. М. Тимофєев, А. В. Шорніков \\ Дз “Дніпропетровська медична академія МОЗ України”
}

\section{USING “LEVEL OF TRAINING” FOR THE STUDENT KNOWLEDGE EVALUATION ON THE CYCLE "PSYCHIATRY. NARCOLOGY”}

\author{
I. D. Spirina, S. V. Rokutov, R. M. Tymofieiev, A. V. Shornikov \\ Dnipropetrovsk Medical Academy
}

\begin{abstract}
Статтю присвячено проблемі теоретичного обгрунтування оцінювання знань студентів з дисципліни “Психіатрія. Наркологія” за допомогою методики “рівнів навчання” за В. П. Беспалько. Наводяться практичні результати досвіду впровадження в навчальний процес означеної методики. Окреслюються подальші перспективи та доцільність впровадження методики, враховуючи необхідність формування компетенцій у майбутніх лікарів.
\end{abstract}

The article deals with the problem of theoretical study evaluating students' knowledge on the subject "Psychiatry. Narcology" using methods of "training levels" for V. P. Bespalko. We give practical results of implementation experience in the educational process of the method. We outline future prospects and feasibility of implementing the methodology, taking into account the need to form competencies for future physicians.

Вступ. Сучасна система підготовки студентів-медиків спирається на компетентнісний підхід. Компетентність - це готовність фахівця до діяльності, стан адекватного виконання завдання. Отже, по відношенню до необхідного рівня виконання людина $є$ або компетентною, або ні. Компетентного фахівця відрізняє здатність вибирати оптимальне серед безлічі рішень, аргументовано спростовувати хибні рішення, ставити під сумнів ефектні, але неефективні рішення [1, 2].

Слід зазначити, що підготовка фахівців у вищих медичних навчальних закладах в останні роки була спрямована перш за все на позитивні результати по іспиту КРОК. Тому використання тільки тестів, в ряді випадків, дозволяє студентам автоматично запам'ятовувати правильні відповіді, не обгрунтовуючи їх. Такий підхід не оцінює компетентність студентів. На думку О. В. Ніколаєвої та Н. А. Шутової, значущим інструментом підготовки майбутніх лікарів повинні бути саме клінічні ситуаційні задачі без варіантів відповідей [3].

3 метою підвищення рівня отриманих знань студентами, для уніфікації оцінки викладачами кафедри знань студентів на практичних та семінарських заняттях і виключення суб’єктивності при оцінці

( I. Д. Спіріна, С. В. Рокутов, Р. М. Тимофєєв, А. В. Шорніков цих знань, а також для оптимізації і стандартизації роботи викладачів, на нашій кафедрі введена багаторівнева система навчання і оцінювання, яка заснована на т. зв. “рівнях навчання” за В. П. Беспалько [4]. Таким чином, виділяються: 1 рівень на цьому рівні відбувається впізнавання раніше вивченого матеріалу. Оцінювання знань, отриманих на цьому рівні, проводиться за допомогою навчальних тестів. Другий рівень навчання $€$ вільною репродукцією отриманих знань. Оцінити його досягнення можливо за допомогою відкритих питань по темі заняття. При цьому основна мета навчання майбутніх лікарів досягається тільки на 3 рівні навчання - це здатність застосовувати знання на практиці, тобто формування навичок і компетенцій. Ми вважаємо, що найбільш адекватно досягнення цього рівня проводиться за допомогою навчальних клінічних завдань, кейс-методами, діловими іграми. Також виділяють 4 рівень навчання, який полягає в творчості, в умінні перенести отримані раніше знання на вирішення нових завдань, нових проблем.

Основна частина. Для подальшої успішної лікарської діяльності випускник медичного вузу повинен володіти знаннями як мінімум 3 рівня, у зв'язку з цим на формування саме цього рівня знань спрямований навчальний процес на кафедрі 
психіатрії, загальної та медичної психології ДЗ “Дніпропетровська медична академія МОЗ України” відповідно до прийнятих освітньо-кваліфікаційних характеристик та освітньо-професійних програм підготовки фахівців за спеціальностями “Медицина” і “Стоматологія”.

Нами проведено дослідження на базі кафедри психіатрії, загальної та медичної психології ДЗ “Дніпропетровська медична академія МОЗ України”. Об’єктом дослідження були 6 навчальних десятків (63 студенти) 4 курсу медичного та стоматологічного факультетів, які не мають академічної заборгованості з дисципліни “Психіатрія. Наркологія”. Ми застосували оцінювання знань 3 урахуванням “рівня навчання” по темі “Психопатологічні синдроми”.

Була використана така структура заняття:

1. Перевірка присутніх.

2. Відповіді на запитання студентів, що виникли при підготовці до занять.

3. Студентам було пояснено суть оцінювання 3 урахуванням “рівня навчання” і методики оцінювання згідно з цими рівнями:

“5” - правильно вирішене завдання (досягнуто 3 рівня знань);

“4” - завдання не вирішено, надано правильну відповідь на питання (досягнуто 2 рівня знань);

“3” - завдання не вирішено, не надано правильну або повну відповідь на питання, надано правильну відповідь на питання (тест) з множинними варіантами вибору (досягнуто 1 рівня знань);

“2” - не вирішена задача, не дано відповіді на запитання, чи не вирішено тест (не досягнуто навіть 1 рівня знань).

4. Кожен студент у довільному порядку отримував клінічну задачу з навчального посібника 3 психіатрії [5]. Студенти, які правильно вирішили задачу, отримували оцінку “відмінно”. У них був досягнутий найвищий рівень знань - здатність застосовувати знання на практиці.

5. Студенти, які вирішили клінічну задачу неправильно, отримували усне питання по темі заняття 3 переліку питань програми навчальної дисципліни “Психіатрія. Наркологія”, що відповідає 2 рівню знань. Всі, хто правильно відповів на нього, отримували оцінку “добре”. Перелік питань доступний студенту заздалегідь у методичних розробках до практичних занять до відповідних тем.

6. Студенти, що не відповіли на питання, отримували в довільному порядку одне питання (тест) з множинними варіантами вибору (1 рівень знань).
Якщо відповідали правильно на нього - отримували оцінку “задовільно”, неправильно - оцінку “незадовільно”. Питання 3 множинними варіантами вибору заздалегідь студентам не відомі.

7. Викладач відповідав на запитання студентів, які виникли під час опитування.

8. Резюме заняття: викладач у максимально стислій і доступній формі розкриває тему практичного заняття, а також надає алгоритми діагностики та лікування.

9. Наприкінці заняття кожен студент оцінював цю методику, відповівши на 2 питання:

1. Чи відповідає отримана ним оцінка, виставлена за допомогою даного методу опитування, його рівню знань?

2. Чи хотіли б вони, щоб і інші заняття проводилися в такій формі?

Оцінки, отримані студентами при опитуванні за допомогою методу “рівня знань”, різнилися від “незадовільно” до “відмінно”. Незважаючи на досить конкретні і точні критерії оцінки знань, більшість студентів відповіла на 1 питання анкети, що отримана за допомогою даної методики опитування оцінка не відповідає їхнім знанням, мотивувавши свою відповідь тим, що надані завдання були різні за складністю. Це почасти також пояснюється тим, що для оцінювання знань студентів частіше застосовують тести або вільне опитування. Крім того, студенти більш орієнтовані на підготовку до ліцензійного іспиту КPOK-2, який проходить у вигляді тестів з однією правильною відповіддю.

Тим не менше, більшість студентів позитивно відповіла на 2 питання анкети, вказавши, що хотіли б, щоб деякі заняття на циклі “Психіатрія. Наркологія” були проведені за даною методикою.

Надалі ми плануємо продовжувати використання “рівнів навчання” для оцінювання знань студентів. Для цього ми розширимо базу клінічних завдань, а також розробимо анонімну анкету для студентів, для більш докладного аналізу моделі оцінювання студентів за допомогою зазначеної методики.

Висновки. Запропонована методика оцінювання студентів, виходячи з рівня навчання, має перспективи у використанні для об’єктивізації оцінки знань студентів медичних та стоматологічних факультетів. До позитивних аспектів пропонованої методики відносять велику її наближеність до реальної лікарської діяльності, формування лікарських компетенцій, розвиток клінічного мислення у студентів. 


\section{Список літератури}

1. Компетентностный подход в педагогическом образовании / под ред. В. А. Козырева, Н. Ф. Радионовой, А. П. Тряпицыной // Вестник Омского государственного педагогического университета : электронный научный журнал. - СПб. : РГПУ им. А. И. Герцена, 2006. - Режим доступа : www.omsk.edu http://www.omsk.edu/article/ vestnik-omgpu-75.pdf.30 (дата обращения: 25.06.2016).

2. Усачева Е. В. Оценивание уровня сформированности профессиональных компетенций обучающихся ме- дицинского вуза / Е. В. Усачева, Н. А. Гетман // Омский научный вестник. - 2014. - № 2. - С. 160-163.

3. Ніколаєва О. В. Оптимізація оцінювання знань студентів 3 теоретичної медицини на фундаментальних кафедрах в умовах кредитно-трансферної системи / О. В. Ніколаєва, Н. А. Шутова // Медична освіта. - 2016. № 1. - С. 39-40.

4. Наумов Л. Б. Учебные игры в медицине / Л. Б. Наумов. - Т. : Медицина, 1986. - С. 17.

5. Клінічна психіатрія. Збірка задач / за ред. В. П. Блохіної. - Дніпропетровськ, 1991. - 108 с.

Отримано 10.08.16 